\title{
Britain urged to lift barriers to investment in biotechnology
}

London. Britain's biotechnology companies plan to ask the government to make it easier for small start-up ventures registered in Britain to attract capital. The effort, which is being coordinated by the BioIndustry Association (BIA), follows growing evidence that difficulties in raising venture capital domestically is forcing small biotechnology companies into the arms of foreign investors, particularly those from the United States.

Two weeks ago, for example, the Aberdeen-based company Scotgen, which has developed a range of products using "humanized" antibodies that derive from research financed by the Medical Research Council, announced that it was merging with the biotechnology company Vasocor, Inc. of Menlo Park, California. The new company will be called Scotgen Biopharmaceuticals, Inc.

The merger has already allowed the new company to raise an additional $\$ 7$ million in capital, from US investors. Most of the money will go towards clinical trials.

The injection of capital is a windfall for Scotgen's original investors. The University of Aberdeen, which provided laboratory facilities and other assistance in return for an equity stake, could see its investment of tens of thousands of pounds grow in value to several million. Similar gains could accrue to the Scottish Development Agency, another early backer.

But the merger and refinancing also means that US investors will dominate the company's new board of directors. Although Bill Harris, professor of genetics at the University of Aberdeen and founder of Scotgen, who will act as both president and chief scientific officer of the merged company, regrets this shift, he says that "we did not even look in the UK" for new financing because of a previous lack of interest.

The merge also gives Scotgen a US presence that will help it at some point to obtain a public listing on the National Association of Securities Dealers Quotations (NASDAQ) exchange. Cantab Pharmaceuticals of Cambridge pursued the same route last summer when it went public in the United States.

A US listing gives a company greater access to a more aggressive pool of investors and is easier to obtain than a listing on the British Stock Exchange, which places stricter demands on fledgling companies. One particularly difficult standard is the need to show a record of profit making. A recent report by the Advisory Committee on Science and Technology (ACOST) suggesting changes in Stock Exchange rules drew attention to the lack of an efficient "exit

change proposed new guidelines that would, for example, drop the profitable trading requirement. But the exchange still wants companies that apply to hold (or expect to gain) the rights to a number of patents and to have at least two drugs in clinical trials.

The comment period on these proposals ended last Friday and the response has been mixed. Several companies (and the BIA) have welcomed their general thrust, and have proposed some minor changes. But financial analysts are concerned that the rules are likely to remain relatively conservative.

"If the situation continues, the City of London will continue to lose out on a great opportunity", says Caroline Vaughan of Newmarket Management Services. "We must be among the top two or three countries in the world in terms of technical capability [in biotechnology], but the downstream benefit is going to go to NASDAQ and the US." The director of the BIA, Louis da Gama, says that the BIA intends to ask the Department of Trade and Industry to address a range of issues that make investment opportunities in biotechnology less attractive in Britain.

In the meantime, scientists working in university and research council laboratories report an in-

route" for initial investors in British companies who, unlike their US counterparts, are required to stick with a company until it shows a profit.

Shortly before Christmas, the Stock Ex- creasing number of enquiries from foreign investors. In several cases, the offers would involve buying the rights to fundamental research results and developing them in USbased laboratories.

David Dickson

\section{Research council takes stake in start-up}

London. The Medical Research Council (MRC) has accepted a significant equity stake in a new company created to exploit research funded by the council in gene therapy technology. The company, known as Therexsys, hopes to develop a gene therapy technique that targets therapeutically effective genes to human cells without using more conventional vectors such as retroviruses and adenoviruses.

Both the MRC and the Cancer Research Campaign (CRC) - through its technology transfer arm, CRC Technology - have taken equity in the company in return for access to their respective research facilities, and in MRC's case for the exclusive rights to patents on research carried out at the council's National Institute for Medical Research
(NIMR) in London.

If the techniques prove successful, both organizations will be able to reap substantial rewards by selling their stakes either when a new round of financing takes place, planned for later this year, or when the company eventually goes public.

Therexsys was set up last summer with seed money from three British venture capital funds, Biotechnology Investments, Ltd. (the venture capital arm of the merchant bankers N M Rothschild), Schroder Ventures and $3 \mathrm{i}$. It is being run from a science park in the northwest of England by Roger Craig, formerly professor of biochemistry at Middlesex Hospital Medical School in London, and until last year head of biotechnology for ICI Pharmaceuticals. 
Therexsys hopes to develop an approach to gene therapy in which genes are accurately targeted and regulated. The technology could be applicable to both acute and, eventually, chronic therapy in a number of disease areas, including cancer, cardiovascular disease and the treatment of inflammation.

No details have been released of the precise techniques under development, partly because the company is still in the process of applying for some of the important patents. But they are thought to involve ways of inserting genes into cells using the ability of ligands such as monoclonal antibodies to target tumour and other diseased cells.

The MRC's contribution is based on research on the regulation of gene expression at NIMR by a team led by Frank Grosveld, head of the institute's laboratory of gene structure and expression. Therexsys will have an exclusive licence to the intellectual property, both existing and in future, arising from this work.

The practical application of the techniques will be explored by a research group headed by Mike Dexter, head of the department of experimental haematology at the Paterson Institute of Cancer Research in Manchester. Dexter is widely known for his work on the biology of the stem cells that give rise to blood cell lineages and for his interest in blood-borne tumours, which could be particularly susceptible to the ligandmediated insertion of genes.

Craig has strong links to both the MRC and the CRC. While still at ICI, he belonged to a number of the research council's committees, including its neurosciences committee, its genetics policy group, and the directed programme committee of the Human Genome Mapping Project. He is also a member of the governing committee of the Paterson Institute.

MRC's past efforts to encourage technology transfer from its laboratories have been based primarily on negotiating licencing deals for work from its laboratories, and receiving income through the resulting royalty payments. That was the model for the biotechnology company Celltech, established with government help in 1980. But the company has yet to make a profit, and the return to the MRC so far has been disappointing.

Dai Rees, the secretary of the council, says that the MRC "has now realized the advantage of a mechanism which does not involve royalty deals, but in which we put in the knowledge, taking an equity stake in retum, and other [investors] put in their capital".

The council already has a small equity stake in Cambridge Antibodies, based on work on antibody engineering at its Laboratory for Molecular Biology in Cambridge, and a similar stake in Somatogen, Inc, which works on artificial blood products. In contrast, an equity stake is a new idea for CRC Technology, which plans to return any profits to the CRC through covenants.

David Dickson

\section{Congress asks universities to justify special funding}

Boston. The chairman of the science committee in the US House of Representatives hopes to use US research universities as a wedge for reclaiming political power.

Representative George Brown (Democrat, California) has begun a study of the growing congressional practice of "earmarking' federal dollars for large academic research facilities that have been neither requested by the relevant federal agency nor debated and judged worthy by the entire Congress. Last week Brown mailed a letter to 50 universities that received as much as $\$ 10$ million last year for such projects, asking them to explain themselves.

Brown has fought the growing practice (\$773 million was allocated to some 500 projects last year, triple the amount spend in 1990 ) on the grounds that it subverts the normal process of scientific review and because "it comes out of the hide of existing programs". But he admits that his campaign against so-called academic pork-barrel projects is also part of an effort to reestablish the importance of authorization committees such as his.

"The regular order of Congress requires universities to submit their projects to the appropriate agency and then to have that agency obtain an authorization to do what it wants", Brown explained last week during a press conference at the annual meeting of the American Association for the Advancement of Science (AAAS) in Boston. "Only

\section{Massey says that NSF must tighten its belt}

Washington. The National Science Foundation (NSF) must figure out a way to do its jobdespite insufficient resources, acccording to outgoing director Walter Massey.

Speaking last week with uncharacteristic frankness to a meeting of the National Science Board, NSF's governing body, Massey said that NSF staff must simplify the grantmaking process and lighten its workload because "we aren't going to get the additional resources we need". That concession brings down the curtain on a promise made by presidents Ronald Reagan and George Bush to double the NSF budget within five years and could be a harbinger of the foundation's budget for next year, which will be released on 23 March.

Massey described for the science board the process that he began a year ago to develop a long-range strategy for the foundation. Although work on the strategy is still under way and may never be made into a public document, Massey said that he has asked senior NSF officials by May to draw up details of how to then should they turn to the appropriations process to get the money they need."

"Certain powerful members of Congress", Brown adds, have distorted that process by ignoring the authorizing committees and winning approval for pet projects at the final stage of the legislative process, when committees from each house meet to iron out the details of spending bills. The full Congress rarely has time to scrutinize the work of such conference committees.

For example, Senator Bennett Johnston (Democrat, Louisiana), is chairman of both the authorizing committee for the Department of Energy (DOE) and the appropriations subcommittee that funds it. The dual positions make it possible for Johnston to get money for certain projects without first having the money authorized, a luxury not afforded Brown and most other members of Congress. Perhaps not coincidentally, the energy and water appropriations bill is each year also loaded with such earmarks for universities.

Brown's questionnaire asks universities to describe the type of review their project has undergone and whether they sought approval from any federal agency before approaching Congress. University officials in the past have justified such projects by saying that there is no federal programme to repair and renovate academic research facilities and, thus, no alternative way to obtain such badly needed funds. Jeffrey Mervis

implement it in five critical areas.

"We have to lower the barriers to interdisciplinary work", he said, "and we have to extend our resources by working more closely with other agencies. We need to better integrate education into each of the research directorates, and we need to do business differently to account for the fact that there is no realistic chance our [staff] budget will grow significantly."

The science board decided to spend a good deal of time in the next several months in discussing ways to implement the recommendations of the report last autumn by the Commission on the Future of NSF (Nature 360, 285; 1992). Although it would not be the first time that the science board has sought to play a larger role in defining US science and technology policy, board members believe that their chances of success have improved as a result of several recent reports on the subject and a greater receptiveness to such thinking by the new administration.

Jeffrey Mervis 